\title{
Macadamia Genus: An Updated Review of Phytochemical Compounds and Pharmacological Activities
}

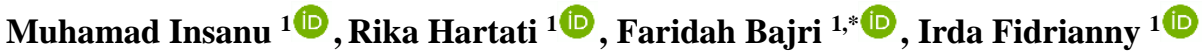 \\ 1 Department of Pharmaceutical Biology, School of Pharmacy, Bandung Institute of Technology, Bandung, Indonesia; \\ muhamad.insanu@gmail.com $\quad$ (M.I.); $\quad$ rika@fa.itb.ac.id $\quad$ (R.H.); $\quad$ faridabajri26@gmail.com $\quad$ (F.B.); \\ irdafidrianny@gmail.com (I.F.); \\ * Correspondence: faridabajri26@gmail.com (F.B.);
}

Received: 7.02.2021; Revised: 2.03.2021; Accepted: 8.03.2021; Published: 22.03.2021

\begin{abstract}
The Macadamia genus of the Proteaceae family, which can be found mainly in the southern hemisphere, has many benefits in some disease treatments. Phytochemical compounds and pharmacological activities of this genus were comprehensively reviewed in this article. This article was written by collecting and reviewing a minimum of 50 scientific articles in PubMed, Google Scholar, Science Direct, Elsevier, and PubChem that contain the phytochemical compounds and pharmacological activities of the Macadamia genus. The articles were published in the last 15 years, a minimum of 20 articles in the last 2 years, and they also must have a DOI. The phytochemical compounds that comprised of flavonoid, proanthocyanidin, and other polyphenols compounds. These phytochemical compounds can promote a wide range of pharmacological activities such as antioxidant, anti-inflammatory, anti-dyslipidemia, dietary controlled, antimicrobial, chemopreventive, and NAFLD prevention. Nevertheless, many investigations on phytochemical compounds and pharmacological activities only focussed on a few parts of a plant, especially nuts. Therefore, further research is needed to determine the other parts of Macadamia genus plants' potential chemical compounds and pharmacological activities.
\end{abstract}

Keywords: Macadamia genus; pharmacological activities; phytochemical compounds.

(C) 2021 by the authors. This article is an open-access article distributed under the terms and conditions of the Creative Commons Attribution (CC BY) license (https://creativecommons.org/licenses/by/4.0/).

\section{Introduction}

The Proteaceae family consists of 80 genera and 1800 species widespread in the southern hemisphere [1]. Proteaceae family grows well in poor-phosphorus soil and has a lowtemperature area $\left(7{ }^{\circ} \mathrm{C}-14{ }^{\circ} \mathrm{C}\right)$, especially in South Western Australia and South Africa [2]. The Macadamia genus is composed of four species, including Macadamia integrifolia Maiden and Betcher, Macadamia jansenii C.L. Gross and P.H. Weston, Macadamia ternifolia F. Muell, and Macadamia tetraphylla L.A.S. Johnson [3].

Macadamia flowers has around $15 \mathrm{~mm}$ long, with one another attached by a short filament to each of four petal-like perianth segments [4]. The fruit of macadamia is identified as a follicle, and it has dark green pericarp color. The part of kernel and nut in the shell as the complete seed is described as a nut. Macadamia kernels consist of two large cotyledons covered by a single layer of epidermal cells [5]. The macadamia tree produces a high-value kernel and oil. Macadamia was harvested 5-6 years after planting [6].

Among four species, only two species produce edible nuts, including Macadamia integrifolia and Macadamia tetraphylla, of which the species most commonly grown for its 
nuts is Macadamia intergrifolia [7]. Those species of the Macadamia genus are evaluated for active compounds and pharmacological activities.

\section{Materials and Methods}

This article was written by collecting and reviewing scientific articles that contain the phytochemical compounds and pharmacological activities of the Macadamia genus. Those articles had been published in the last 15 years, including a minimum of 20 articles in the last 2 years. The articles were presented in PubMed, Google Scholar, Science Direct, Elsevier, and PubChem, which also must have a DOI.

\section{Results and Discussion}

\subsection{Phytochemical compounds of Macadamia genus.}

Macadamia integrifolia and Macadamia tetraphylla produced macadamia oil that contains monounsaturated fatty acids (75\%), where oleic acid being the highest, followed by palmitoleic acid and eicosenoic acid. Saturated fatty acids (15\%) and polyunsaturated fatty acids $(10 \%)$ are also presented in macadamia oil. High concentrations of palmitoleic acid are determined in macadamia nuts (15-22\%) [8]. Hu et al. (2019) stated that palmitoleic acid affected health as well as its association with various diseases, such as obesity, cardiovascular disease, Non-alcoholic Fatty Liver Disease (NAFLD), and Non-alcoholic Steatohepatitis (NASH), diabetes and insulin resistance, also cancer. In previous studies, palmitoleic acid could decrease diabetes, inflammation, and cardiovascular diseases [9].

The chemical compounds in macadamia nut such as sterol, tocopherol, squalene, and total phenolic content were increased by roasting. Meanwhile, tocopherol and thiamine were decreased by roasting. The total polyphenol content increased $25.6 \%$, and the oxidative stability index of kernels increased $21.6 \%$ [10].

The previous studies exposed that the Macadamia genus could produce some secondary metabolites, as shown in Table 1.

Table 1. Phytochemical compounds in Macadamia genus.

\begin{tabular}{|c|c|c|c|}
\hline Macadamia species & Plant part & Compounds & Ref \\
\hline \multirow[t]{6}{*}{ M. integrifolia } & Leaves & $\begin{array}{l}\text { Vit.E, minerals }(\mathrm{K}, \mathrm{Ca}, \mathrm{Na}, \mathrm{Fe}, \mathrm{Cu}) \text {, flavonoids, } \\
\text { tannins }\end{array}$ & {$[11,12]$} \\
\hline & Kernel & Vit.E, minerals $(\mathrm{K}, \mathrm{Ca}, \mathrm{Na}, \mathrm{Fe}, \mathrm{Cu})$ & [11] \\
\hline & Pericarp & Vit.E, minerals (K, $\mathrm{Ca}, \mathrm{Na}, \mathrm{Fe}, \mathrm{Cu})$ & [11] \\
\hline & Flowers & Flavonoids, tannins & [12] \\
\hline & Nut & $\begin{array}{l}\text { Proanthocyanidins, phenolic acids, phytates, } \\
\text { lipids (myristic, palmitic, palmitoleic, oleic, } \\
\text { linoleic, stearic, elaidic, arachidic, eicosenoic), } \\
\text { minerals ( } \mathrm{Na}, \mathrm{Al}, \mathrm{B}, \mathrm{Ca}, \mathrm{Cu}, \mathrm{Fe}, \mathrm{K}, \mathrm{Mg}, \mathrm{Mn}, \mathrm{Na} \text {, } \\
\mathrm{P}, \mathrm{S}, \mathrm{Zn} \text { ), }\end{array}$ & {$[13,14]$} \\
\hline & Oil & $\begin{array}{l}\text { Lipids (lauric, myristic, palmitic, palmitoleic, } \\
\text { margaric, isomargaric, heptadecanoic, } \\
\text { heptadecenoic, stearic, arachidic, oleic, trans- } \\
\text { vaccenic, linoleic, } \alpha \text {-linolenic, gadoleic, behenic, } \\
\text { cetoleic, arachidonic, erucic), minerals (Na, Mg, } \\
\mathrm{K}, \mathrm{Ca}, \mathrm{Zn}, \mathrm{Fe}, \mathrm{P}, \mathrm{F} \text { ), amino acids (alanine, glycine, } \\
\text { valine, leucine, isoleucine, proline, cysteine, } \\
\text { methionine, phenylalanine, serine, threonine, } \\
\text { tyrosine, aspartic acid, glutamic acid, lysine, } \\
\text { arginine, histidine), apigenin 7-glucoside, } \\
\text { luteolin, caffeic acid, p-hydroxybenzoic acid, } \\
\text { squalene, } \alpha \text {-tocopherol, } \gamma \text {-tocopherol, } \alpha \text { - } \\
\text { tocotrienol, } \gamma \text {-tocotrienol, } \delta \text {-tocotrienol }\end{array}$ & {$[8,15-20]$} \\
\hline
\end{tabular}




\begin{tabular}{|c|c|c|c|}
\hline Macadamia species & Plant part & Compounds & Ref \\
\hline \multirow[t]{2}{*}{ M. tetraphylla } & Oil & $\begin{array}{l}\text { Lipids (lauric, myristic, palmitic, palmitoleic, } \\
\text { stearic, arachidic, oleic, linoleic, } \alpha \text {-linolenic, } \\
\text { gadoleic, behenic, cetoleic) }\end{array}$ & [8] \\
\hline & Skin & Flavonoids, proanthocyanidins & [7] \\
\hline \multirow[t]{3}{*}{ Macadamia sp. } & Nut & $\begin{array}{l}\text { Flavonoids, proanthocyanidins, phytosterols } \\
\text { (campesterol, clerosterol, } \beta \text {-sitosterol, } \\
\text { campestanol, } \Delta^{5} \text {-avenasterol + } \beta \text {-sitostanol, } \\
\Delta^{5,24(25)} \text {-stigmastadienol, } \Delta^{7} \text {-stigmastenol, 24- } \\
\text { methylenecycloartenol, citrostadienol), amino } \\
\text { acids (alanine, glycine, valine, leucine, } \\
\text { isoleucine, proline, cysteine, methionine, } \\
\text { phenylalanine, serine, threonine, tyrosine, } \\
\text { aspartic acid, glutamic acid, lysine, arginine, } \\
\text { histidine), lipids (lauric, myristic, palmitic, } \\
\text { stearic, arachidic, behenic, palmitoleic, oleic, } \\
\text { gadoleic, linoleic, } \alpha \text {-linolenic), minerals (Fe, Zn, } \\
\text { Cu, As, Ca, Cr, Mg, Mn, K, Na, P), proteins } \\
\text { (serotonin, legumins, vicilins, and } 2 \mathrm{~S} \text { albumins), } \\
\text { polyphenols, catechin, epicatechin, } \gamma \text {-tocopherol, } \\
\alpha \text {-tocotrienol, } \gamma \text {-tocotrienol, glucose, fructose, } \\
\text { sucrose }\end{array}$ & [21-30] \\
\hline & Hard shell & $\begin{array}{l}\text { 2,6-dihydroxybenzoic acid, 3,5-dimethoxy-4- } \\
\text { hydroxycinnamic acid }\end{array}$ & {$[31]$} \\
\hline & Oil & $\begin{array}{l}\text { Tocols, phytosterols, lipids (myristic, behenic, } \\
\text { lauric, palmitic, palmitoleic, margaric, stearic, } \\
\text { elaidic, oleic, linoleic, linolenic, arachidic, } \\
\text { gonodic, EPA, behenoic, erucic, DHA, } \\
\text { lignoceric), amino acids (lysine, methionine, } \\
\text { threonine, tryptophan, phenylalanine, histidine, } \\
\text { valine, isoleucine, leucine, arginine, cysteine, } \\
\text { proline, glutamic acid, tyrosine, serine), } \\
\text { polysaccharides (cellulose, glucose, xylose, } \\
\text { arabinose, galactose, mannose, rhamnose, fucose) }\end{array}$ & {$[13,32,33]$} \\
\hline
\end{tabular}

\subsection{Pharmacological activities of Macadamia genus.}

\subsubsection{Antioxidant activity.}

Macadamia nuts (kernel and skin) revealed antioxidant activity in various studies due to their rich-total phenolic content. Extraction of $M$. tetraphylla skin using a mixture of acetone - water $(1: 1)$ as a solvent and optimized by ultrasonic extraction showed antioxidant potential in ABTS (2,2'azino-bis (3-ethylbenzethiazoline-6-sulfonic acid), DPPH (2,2 diphenyl-1picrylhidrazyl), CUPRAC (Cupric Ion Reducing Antioxidant Capacity), and FRAP (Ferric Reducing Antioxidant Power) methods with the value were $102.36 \mu \mathrm{M}$ TE/g, $1128.76 \mu \mathrm{M}$ Trolox Equivalent (TE)/g, $2736.31 \mu \mathrm{M}$ TE/g, and $1607.82 \mu \mathrm{M}$ TE/g, respectively [34].

Phytochemical extract of Macadamia nut had $\mathrm{EC}_{50} 13.4 \mu \mathrm{mol}$ vitamin $\mathrm{C}$ equivalent/g sample using TOSC (Total Oxyradical Scavenging Capacity) method [35]. Furthermore, Macadamia nut's methanol extracts' antioxidant efficacy had IC 50 values $3 \mu \mathrm{m}$ and $4.1 \mu \mathrm{m}$ for raw nut and roasted nut, respectively [36]. Research by Garg et al. (2007) demonstrated that plasma levels of 8-isoprostane (a reliable in vivo marker of oxidative stress) were reduced by $18.9 \%$ after macadamia nut intervention [37]. The other research by Vadivel et al. (2012) mentioned that diet macadamia nuts given by single feeding would improve oxidation status [38]. 
<smiles>COc1c(O)cc(C2Oc3c(O)cc(O)c([C@H]4c5c(O)cc(O)cc5O[C@H](c5ccc(O)cc5)[C@H]4O)c3O2)cc1O</smiles>

Proanthocyanidin<smiles>Oc1cc(O)c2c(c1)OC(c1ccc(O)c(O)c1)C(O)C2</smiles>

Catechin<smiles>O=P([O-])([O-])O[C@@H]1[C@H](OP(=O)([O-])O)[C@@H](OP(=O)([O-])O)[C@@H](OP(=O)(O)O)[C@@H](OP(=O)([O-])O)[C@@H]1OP(=O)([O-])[O-]</smiles>

Phytate

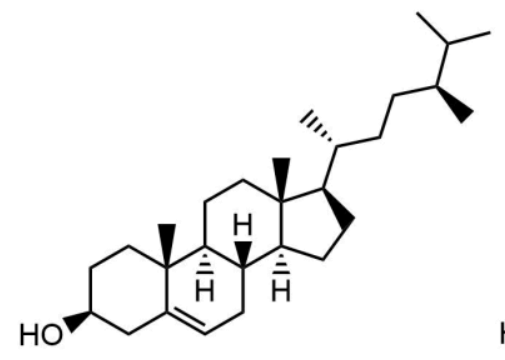

Campesterol

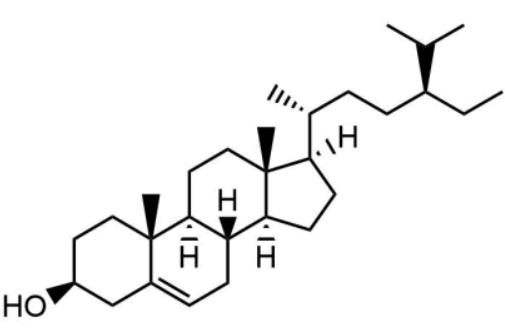

$\beta$-sitosterol

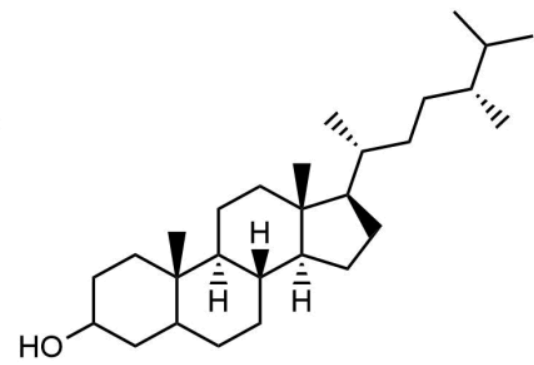

Campestanol

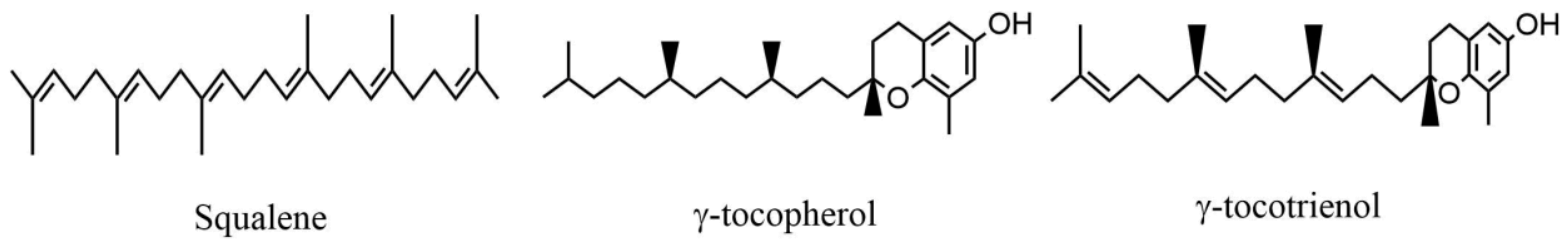<smiles>CCCCCCCCCCCCCC(=O)O</smiles>

Myristic acid<smiles>CCCCCCCCCCCCCCCCC(=O)O</smiles>

Palmitic acid<smiles>CCCCCC=CCC=CCCCCCCCC(=O)O</smiles>

Linoleic acid

Figure 1. Structure of chemical compounds from Macadamia genus.

The DPPH radical scavenging activity of the macadamia oil was $0.17 \mathrm{mM}$ TAEC/kg, and the ratio of Lipophilic Fractions (LF)/Hydrophilic Fractions (HF) was $1.31 \mathrm{mM}$ TEAC/kg [39]. Meanwhile, the total lipid-soluble antioxidant capacity of the $M$. integrifolia kernel oils from seven cultivars in Hawaii measured by photo-chemiluminescent (PCL) inhibition assay ranged from 42.53 to $65.78 \mathrm{nmol} \mathrm{TE} / \mathrm{g}$ oil in 2006 and from 37.48 to $46.81 \mathrm{nmol} \mathrm{TE} / \mathrm{g}$ oil in 2007. Macadamia kernels contained significant amounts of tocotrienol (T3) and squalene, and these phytochemicals may confer antioxidant activity [19]. The antioxidant activity of macadamia nut peptide with different molecular weights was evaluated by the DPPH method, and the result showed DPPH free radical scavenging activity $80.97 \%$. By increasing the concentration of the protein-peptide component, its antioxidant activity also increased [40].

\subsubsection{Antimicrobial activity.}

M. integrifolia seeds, leaves, and flowers have been investigated for their antimicrobial activity in some researches. $M$. integrifolia seeds containing the antimicrobial peptide named MiAMP1 ( $\beta$-barrelins). The MiAMP1 could protect against various phytopathogenic fungi and Gram-positive bacteria with a concentration range of $0.2-2 \mu \mathrm{M}$ [41]. 
Five extracts (methanol, water, ethyl acetate, chloroform, and hexane) of $M$. integrifolia leaves and flowers displayed antimicrobial activities in the disc diffusion assay. All flower extracts inhibited the growth of 7 bacteria tested (A. hydrophilia, C. freundi, E. coli, $P$. mirabilis, S. marcenscens, S. sonnei, and B. cereus) and all 3 of the fungi tested (A. niger, $C$. albicans, and $S$. cerevisiae). Meanwhile, all leaves extracts inhibited the growth of six bacterial species tested (A. hydrophilia, C. freundi, E. coli, P. mirabilis, P. fluroscens, and $S$. marcenscens) and two of the fungi tested (C. albicans, and S. cerevisiae) [12].

$M$. integrifolia nuts and leaves that extracted by methanol and water expressed antimicrobial properties against $P$. mirabilis. The minimum inhibitory concentration (MIC) of methanol extracts were $15 \mu \mathrm{g} / \mathrm{ml}$ and $2790 \mu \mathrm{g} / \mathrm{ml}$ for nuts and leaves, respectively. Besides, water extracts had MIC values $558 \mu \mathrm{g} / \mathrm{ml}$ and $4378.2 \mu \mathrm{g} / \mathrm{ml}$ for nuts and leaves, respectively [42]. However, only methanol extract from $M$. integrifolia flowers from Australia was reported to inhibit $A$. hydrophilia using disc diffusion assay [43]. M. integrifolia oil also showed inhibitory activity against Pseudomonas aeruginosa with MIC > 2.0\% v/v [44].

\subsubsection{Anti-dyslipidemia activity.}

Macadamia nuts intake on 25 mildly hypercholesterolemic subjects for 5 weeks resulted in a significant decrease of total cholesterol (from 5.66 to $4.94 \mathrm{mmol} / \mathrm{l}$ ), Low-Density Lipoprotein (LDL)-cholesterol (from 3.68 to $3.14 \mathrm{mmol} / \mathrm{l}$ ), and non- High-Density Lipoprotein (HDL) cholesterol (from 4.41 to $3.83 \mathrm{mmol} / \mathrm{l}$ ) due to their high- monounsaturated fatty acid MUFA contents, especially palmitoleic and oleic acid [45]. Macadamia nuts consumption also reduced overweight subjects' total cholesterol from 5.38 to $5.1 \mathrm{mmol} / \mathrm{l}$ [46]. Mixed nuts, indeed macadamia nuts, showed significant decreases in triglycerides, total cholesterol, and non-HDL cholesterol [47].

Many literature reviews exhibited the effect of macadamia nuts on reducing triglycerides, total cholesterol, and LDL-cholesterol. Macadamia nut consumption on hypercholesterolaemic and overweight subjects could decrease triglycerides in 5-10 weeks [48]. Diet enriched with macadamia nuts on 14 subjects with hypercholesterolemia for 5 weeks also reduced total cholesterol and LDL-cholesterol [49]. Meanwhile, recent well-controlled intervention studies with macadamias showed LDL-cholesterol reductions ranging from $4 \%$ to $11 \%$ versus comparator diets, confirming macadamia nut's cholesterol-lowering efficacy [50].

MUFA-rich content in macadamia nuts is likely to affect cardiovascular health [51] beneficially. Alasalvar et al . (2020) reported that macadamia nut consumption was suggested by Food and Drug Association (FDA) to reduce coronary heart disease (CHD) risk [52].

\subsubsection{Anti-inflammatory activity.}

Cell culture experiments were performed using murine macrophages (RAW264.7) to study macadamia oily nut extract's capacity to modulate inflammatory processes by chromatographic analysis. The results showed that macadamia oily nut extract significantly reduced the lipopolysaccharide (LPS)-induced expression of iNos, Tnf $\alpha$, Il1 $\beta$, and Il6 mRNAs of RAW264.7 macrophages up to 71\%, 29\%, 57\%, and 27\%, respectively [53].

Moreover, macadamia nut consumption (equivalent to $15 \%$ energy intake) for 4 weeks resulted in a $22.5 \%$ reduction of leukotriene $\mathrm{B}_{4} \mathrm{LTB}_{4}$ (plasma markers of inflammation) concentration in the plasma [37]. Mixed nuts containing macadamia nuts could also reduce 
hepatic expression of siklooksigenase-2 COX-2, which produces pro-inflammatory prostaglandins from arachidonic acid [47].

\subsubsection{Dietary controlled.}

The previous research stated that consumption of macadamia oil and high fat showed a decrease in body mass index in rats $\left(5.8 \mathrm{~kg} / \mathrm{m}^{2}\right)$ compared to only high fat consumption $(6.2$ $\mathrm{kg} / \mathrm{m}^{2}$ ) [54]. Kim et al. (2017) reported that macadamia nuts in a nut-enriched diet on 101 overweight subjects for 18 months could decrease $1.6 \mathrm{~kg} / \mathrm{m}^{2}$ BMI, $6.9 \mathrm{~cm}$ waist circumference, and $4.1 \mathrm{~kg}$ body weight in the moderate-fat group, while decreased $1.4 \mathrm{~kg} / \mathrm{m}^{2} \mathrm{BMI}, 2.6 \mathrm{~cm}$ waist circumference and $2.9 \mathrm{~kg}$ body weight in the low-fat group [49]. Dietary supplement capsules of macadamia oil contained nutritional and health-maintenance properties, such as polyunsaturated fatty acids (2.8-4.7\%) and large amounts of monounsaturated fatty acids (80\%) [55].

\subsubsection{Anti-tyrosinase activity.}

El Hawary et al. (2020) evaluated the extract's anti-tyrosinase activity, fractions, and isolated compound from macadamia. The results showed extract had tyrosinase inhibitory activity IC50 $85 \mathrm{mg} / \mathrm{ml}$ and ethyl acetate fraction $60 \mathrm{mg} / \mathrm{ml}$ and n-butanol fraction $75 \mathrm{mg} / \mathrm{ml}$. Meanwhile, gallic acid had a strong anti-tyrosinase activity with $\mathrm{IC}_{50} 56 \mathrm{mg} / \mathrm{ml}$ [56].

\subsubsection{Chemopreventive activity.}

Macadamia nut fermentation produced $19.59 \mathrm{mmol} / \mathrm{l}$ of butyrate acid (one of the main short-chain fatty acids), whereas it could inhibit proliferation and induced apoptosis and differentiation in colon cancer cells histone deacetylase inhibitor [57]. The macadamia nuts extract exposed weak antiproliferative activity to inhibit Caco-2 colon cancer cell proliferation with $\mathrm{EC}_{50}$ values $86.9 \mathrm{mg} / \mathrm{ml}$ [35].

\subsubsection{Non-alcoholic fatty liver disease (NAFLD) prevention activity.}

Hepatic steatosis belongs to non-alcoholic fatty liver disease (NAFLD) correlated to fructose/sucrose-induced hepatic lipogenesis. Research by Siddiqui et al. (2015) demonstrated that macadamia nut oils could inhibit the development of sucrose/fructose-induced hepatic steatosis in C57BL/6 mice due to high-unsaturated fatty acids content [58].

\section{Conclusions}

The Macadamia genus had various phytochemical compounds and pharmacological activities. Macadamia genus's phytochemical compounds had few pharmacological activities such as antioxidant, anti-inflammatory, anti-dyslipidemia, and antimicrobial. Further research is required to explore the other parts of Macadamia genus plants' potential chemical constituents and pharmacological activities.

\section{Funding}

This research received no external funding. 


\section{Acknowledgments}

The authors wish to respect the Department of Pharmaceutical Biology facilities, School of Pharmacy, Bandung Institute of Technology, Indonesia.

\section{Conflicts of Interest}

The authors declare no conflict of interest.

\section{References}

1. Mast, A.R.; Willis, C.L.; Jones, E.H.; Downs, K.M.; Weston, P.H. A smaller Macadamia from a more vagile tribe: Inference of phylogenetic relationships, divergence times, and diaspore evolution in macadamia and relatives (tribe Macadamieae; Proteaceae). Am J Bot 2008, 95, 843-870, https://doi.org/10.3732/ajb.0700006.

2. Delgado, M.; Valle, S.; Reyes-Díaz, M.; Barra, P.J.; Zúñiga-Feest, A. Nutrient use efficiency of southern south america proteaceae species. Are there general patterns in the proteaceae family? Front Plant Sci 2018, 9, 1 12, https://doi.org/10.3389/fpls.2018.00883.

3. Mai, T.; Alam, M.; Hardner, C.; Henry, R.; Topp, B. Genetic structure of wild germplasm of macadamia: Species assignment, diversity and phylogeographic relationships. Plants 2020, 9, 1-17, https://doi.org/10.3390/plants9060714.

4. Trueman, S.J. The reproductive biology of macadamia. Sci Hortic (Amsterdam) 2013, 150, 354-359, https://doi.org/10.1016/j.scienta.2012.11.032.

5. Susilowati, A.; Kusuma, Y.S.; Kholibrina, C.R. Seed morphology and germination of Macadamia (Macadamia integrifolia) from North Sumatra. IOP Conf Ser Earth Environ Sci 2019, 260, https://doi.org/10.1088/1755-1315/260/1/012164.

6. Hardner, C.; Silva, J.C.; Williams, E.; Meyers, N.; McConchie, C. Breeding new cultivars for the Australian macadamia industry. HortScience 2019, 54, 621 - 628, https://doi.org/10.21273/HORTSCI13286-18.

7. Dailey, A.; Vuong, Q.V. Optimization of aqueous extraction conditions for recovery of phenolic content and antioxidant properties from macadamia (Macadamia tetraphylla) skin waste. Antioxidants 2015, 4, 699 718, https://doi.org/10.3390/antiox4040699.

8. Aquino-Bolaños, E.N.; Mapel-Velazco, L.; Martín-del-Campo, S.T.; Chávez-Servia, J.L.; Martínez, A.J.; Verdalet-Guzmán, I. Fatty acids profile of oil from nine varieties of Macadamia nut. Int J Food Prop 2017, 20, 1262 - 1269, https://doi.org/10.1080/10942912.2016.1206125.

9. Hu, W.; Fitzgerald, M.; Topp, B.; Alam, M.; O'Hare, T.J. A review of biological functions, health benefits, and possible de novo biosynthetic pathway of palmitoleic acid in macadamia nuts. J Funct Foods 2019, 62, 103520, https://doi.org/10.1016/j.jff.2019.103520.

10. Tu, X.H.; Wu, B.F.; Xie, Y.; Xu, S.L.; Wu, Z.Y.; Lv, X.; Wei, F.; Du, L.Q.; Chen, H. A comprehensive study of raw and roasted macadamia nuts: Lipid profile, physicochemical, nutritional, and sensory properties. Food Sci Nutr 2021, 1, 1 - 10, https://doi.org/10.1002/fsn3.2143.

11. Abubaker, M.; El Hawary, S.S.; Mahrous, E.A.; El-Kader, E.M.A. Study of Nutritional Contents of Macadamia integrifolia Maiden and Betche Leaves, Kernel and Pericarp Cultivated in Egypt. Int J Pharmacogn Phytochem Res 2018, 9, https://doi.org/10.25258/phyto.v9i12.11189.

12. Boyer, H.; Cock, I. Evaluation of the potential of Macadamia integrifolia extracts as antibacterial food agents. Pharmacogn Commun 2013, 3, 53 - 62, https://doi.org/10.5530/pc.2013.3.10.

13. Alasalvar, C.; Bolling, B.W. Review of nut phytochemicals, fat-soluble bioactives, antioxidant components and health effects. Br J Nutr 2015, 113, S68 - S78, https://doi.org/10.1017/S0007114514003729.

14. Richards, T. E.; Kämper, W.; Trueman, S.J.; Wallace, H.M.; Ogbourne, S.M.; Brooks, P.R.; Nichols, J.; Bai, S.H. Relationships between nut size, kernel quality, nutritional composition and levels of outcrossing in three macadamia cultivars. Plants 2020, 9,10 - 14, https://doi.org/10.3390/plants9020228.

15. Rengel, A.; Pérez, E.; Piombo, G.; Ricci, J.; Servent, A.; Tapia, M.S.; Gibert, O.; Montet, D. Lipid profile and antioxidant activity of Macadamia nuts (Macadamia integrifolia) cultivated in Venezuela. Nat Sci 2015, 7, 535 - 547, https://doi.org/10.4236/ns.2015.712054.

16. Carrillo, W.; Carpio, C.; Morales, D.; Vilcacundo, E.; Álvarez, M. Fatty acids composition in macadamia sedes oil (Macadamia integrifolia) from Ecuador. Asian J Pharm Clin Res 2017, 10, 303 - 306, https://doi.org/10.22159/ajpcr.2017.v10i2.15618. 
17. Cicero, N.; Albergamo, A.; Salvo, A.; Bua, G.P.; Bartolomeo, G.; Mangano, V.; Rotondo, A.; Stefano, V.D.; Bella, G.D.; Dugo, G. Chemical characterization of a variety of cold-pressed gourmet oils available on the Brazilian market. Food Res Int 2018, 109, 517 - 525, https://doi.org/10.1016/j.foodres.2018.04.064.

18. Nkosi, B.D.; Phenya, J.S.M.; Malebana, I.M.M.; Muya, M.C.; Motiang, M.D. Nutrient evaluation and ruminal degradation of dry matter and protein from amarula (Sclerocarya birrea), macadamia (integrifolia) and baobab (Adansonia digitata L.) oilcakes as dietary supplements for ruminants. Trop Anim Health Prod 2019, 51, 1981 - 1988, https://doi.org/10.1007/s11250-019-01896-0.

19. Wall, M.M. Functional lipid characteristics, oxidative stability, and antioxidant activity of macadamia nut (Macadamia integrifolia) cultivars. Food Chem 2010, $121, \quad 1103 \quad$ - $\quad 1108$, https://doi.org/10.1016/j.foodchem.2010.01.057.

20. Ribeiro, A.P.L.; Haddad, F.F.; Tavares, T.de.S.; Magalhães, K.T.; Pimenta, C.J.; Nunes, C.A. Characterization of macadamia oil (Macadamia integrifolia) obtained under different extraction conditions. Emirates J Food Agric 2020, 32, 295 - 302, https://doi.org/10.9755/ejfa.2020.v32.i4.2095.

21. Bolling, B.W.; Chen, C.Y.O.; McKay, D.L.; Blumberg, J.B. Tree nut phytochemicals: Composition, antioxidant capacity, bioactivity, impact factors. A systematic review of almonds, Brazils, cashews, hazelnuts, macadamias, pecans, pine nuts, pistachios and walnuts. Nutr Res Rev 2011, 24, $244-275$, https://doi.org/10.1017/S095442241100014X.

22. Yılmaz, C.; Taş, N.G.; Kocadağlı, T.; Gökmen, V. Determination of serotonin in nuts and nut containing products by liquid chromatography tandem mass spectrometry. Food Chem 2019, 272, 347 - 353, https://doi.org/10.1016/j.foodchem.2018.08.064.

23. Chung, K.H.; Shin, K.O.; Hwang, H.J.; Choi, K.S. Chemical composition of nuts and seeds sold in Korea. Nutr Res Pract 2013, 7, 82 - 88, https://doi.org/10.4162/nrp.2013.7.2.82.

24. Franke, A.A.; Murphy, S.P.; Lacey, R.; Custer, L.J. Tocopherol and tocotrienol levels of foods consumed in Hawaii. J Agric Food Chem 2007, 55, 769 - 778, https://doi.org/10.1021/jf0623844.

25. Bittner, K.; Rzeppa, S.; Humpf, H.U. Distribution and quantification of flavan-3-ols and procyanidins with low degree of polymerization in nuts, cereals, and legumes. J Agric Food Chem 2013, 61, 9148 - 9154 , https://doi.org/10.1021/jf4024728.

26. Lara, D.; Vilcacundo, E.; Carrillo, C.; Carpio, C.; Silva, M.; Alvarez, M.; Carrillo, W. Obtention of protein concentrate and polyphenols from Macadamia (Macadamia integrifolia) with aqueous extraction method. Asian J Pharm Clin Res 2017, 10, 138 - 142, https://doi.org/10.22159/ajpcr.2017.v10i2.14808.

27. Moodley, R.; Kindness, A.; Jonnalagadda, S.B. Elemental composition and chemical characteristics of five edible nuts (almond, Brazil, pecan, macadamia and walnut) consumed in Southern Africa. J Environ Sci Heal Part B Pestic Food Contam Agric Wastes 2007, 42, 585 - 591, https://doi.org/10.1080/03601230701391591.

28. Robbins, K.S.; Shin, E.C.; Shewfelt, R.L.; Eitenmiller, R.R.; Pegg, R.B. Update on the healthful lipid constituents of commercially important tree nuts. J Agric Food Chem 2011, 59, 12083 - 12092 , https://doi.org/10.1021/jf203187v.

29. Schlörmann, W.; Birringer, M.; Böhmc, V.; Löber, K.; Jahreis, G.; Lorkowski, S.; Müller, A.K.; Schöne, F.; Glei, M. Influence of roasting conditions on health-related compounds in different nuts. Food Chem 2015, 180, 77 - 85, https://doi.org/10.1016/j.foodchem.2015.02.017.

30. Zhong, L.; Bornman, J.F.; Wu, G.; Hornoff, A.; Dovi, K.A.P.; AL-Ali, H.; Aslam, N.; Johnson, S.K. The nutritional and phytochemical composition of the indigenous australian pindan walnut (Terminalia cunninghamii) kernels. Plant Foods Hum Nutr 2017, 73, 40 - 46, https://doi.org/10.1007/s11130-017-06479.

31. Chang, S.K.; Alasalvar, C.; Bolling, B.W.; Shahidi, F. Nuts and their co-products: The impact of processing (roasting) on phenolics, bioavailability, and health benefits - A comprehensive review. J Funct Foods 2016, 26, 88 - 122, https://doi.org/10.1016/j.jff.2016.06.029.

32. Tiwari, U.P.; Jha, R. Nutrients, amino acid, fatty acid and non-starch polysaccharide profile and in vitro digestibility of macadamia nut cake in swine. Anim Sci J 2017, 88, $1093 \quad$ - 1099 , https://doi.org/10.1111/asj.12750.

33. O’Hare, T.J.; Trieu, H.H.; Topp, B.; Russell, D.; Pun, S.; Torrisi, C.; Liu, D. Assessing fatty acid profiles of macadamia nuts. HortScience 2019, 54, 637 - 633, https://doi.org/10.21273/HORTSCI13418-18.

34. Dailey, A.; Vuong, Q. Optimisation of ultrasonic conditions as an advanced extraction technique for recovery of phenolic compounds and antioxidant activity from Macadamia (Macadamia tetraphylla) skin waste. Technologies 2015, 3, 302 - 320, https://doi.org/10.3390/technologies3040302. 
35. Yang, J.; Liu, R.H.; Halim, L. Antioxidant and antiproliferative activities of common edible nut seeds. LWT Food Sci Technol 2009, 42, 1 - 8, https://doi.org/10.1016/j.lwt.2008.07.007.

36. Vinson, J.A.; Cai, Y. Nuts, especially walnuts, have both antioxidant quantity and efficacy and exhibit significant potential health benefits. Food Funct 2012, 3, 134 - 140, https://doi.org/10.1039/c2fo10152a.

37. Garg, M.L.; Blake, R.J.; Wills, R.B.H.; Clayton, E.H. Macadamia nut consumption modulates favourably risk factors for coronary artery disease in hypercholesterolemic subjects. Lipids 2007, 42, 583 - 587, https://doi.org/10.1007/s11745-007-3042-8.

38. Vadivel, V.; Kunyanga, C.N.; Biesalski, H.K. Health benefits of nut consumption with special reference to body weight control. Nutrition 2012, 28, 1089 - 1097, https://doi.org/10.1016/j.nut.2012.01.004.

39. Prescha, A.; Grajzer, M.; Dedyk, M.; Grajeta, H. The antioxidant activity and oxidative stability of coldpressed oils. JAOCS J Am Oil Chem Soc 2014, 91, 1291 - 1301, https://doi.org/10.1007/s11746-014-2479-1.

40. Xixiang, S.; Ming, Z.; Feiyue, M.A.; Liqing, D.U.; Qiuhong, L.I.; Xinghao, T.U. Preparation and antioxidant activities of macadamia nut peptides by combined enzymatic hydrolysis. Chinese Journal of Tropical Crops 2020, 41, 1434 - 1439, https://doi.org/10.3969/j.issn.1000-2561.2020.07.021.

41. Santos-Silva, C.A.; Zupin, L.; Oliveira-Lima, M.; Vilela, L.M.B.; Bezerra-Neto1, J.P.; Ferreira-Neto1, J.R.; Ferreira, J.D.C.; Oliveira-Silva, R.L.; Pires, C.de.J.; Aburjaile, F.F.; Oliveira, M.F.; Kido, E.A.; Crovella, S.; Benko-Iseppon, A.M. Plant antimicrobial peptides: state of the art, in silico prediction and perspectives in the omics era. Bioinform Biol Insights 2020, 14, https://doi.org/10.1177/1177932220952739.

42. Cock, I.; Winnett, V.; Sirdaarta, J.; Matthews, B. The potential of selected Australian medicinal plants with anti-Proteus activity for the treatment and prevention of rheumatoid arthritis. Pharmacogn Mag 2015, 11, 190, https://doi.org/10.4103/0973-1296.157734.

43. Cock, I.E. Antibacterial activity of selected australian native plant extracts. Internet J Microbiol 2012, 4, https://doi.org/10.5580/8d1.

44. Leja, K.; Szudera-Kończal, K.; Myszka, K.; Czaczyk, K. Antibacterial effect of natural oils - an opportunity to solve the problem of antibiotic resistance on the example of Pseudomonas spp. Postępy Mikrobiol Adv Microbiol 2019, 58, 177 - 190, https://doi.org/10.21307/pm-2019.58.2.177.

45. Griel, A.E.; Cao, Y.; Bagshaw, D.D.; Cifelli, A.M.; Holub, B.; Kris-Etherton, P.M. A macadamia nut-rich diet reduces total and LDL-cholesterol in mildly hypercholesterolemic men and women. $J$ Nutr 2008, 138, 761 - 767, https://doi.org/10.1093/jn/138.4.761.

46. Somerset, S.M.; Graham, L.; Markwell, K. Isoenergetic replacement of dietary saturated with monounsaturated fat via macadamia nuts enhances endothelial function in overweight subjects. ESPEN $J$ 2013, 8, e113 - e119, https://doi.org/10.1016/j.clnme.2013.02.003.

47. Hong, M.Y.; Groven, S.; Marx, A.; Rasmussen, C.; Beidler, J. Anti-inflammatory, antioxidant, and hypolipidemic effects of mixed nuts in atherogenic diet-fed rats. Molecules 2018, 23, https://doi.org/10.3390/molecules23123126.

48. Mejia, S.B.; Kendall, C.W.C.; Viguiliouk, E.; Augustin, L.S.; Ha, V.; Cozma, A.I.; Mirrahimi, A; Maroleanu, A.; Chiavaroli, L.; Leiter, L.A.; Souza, R.J.; Jenkins, D.J.A.; Sievenpiper, J.L. Effect of tree nuts on metabolic syndrome criteria: A systematic review and meta-analysis of randomised controlled trials. BMJ Open 2014, 4, https://doi.org/10.1136/bmjopen-2013-004660.

49. Kim, Y.; Keogh, J.B.; Clifton, P.M. Benefits of nut consumption on insulin resistance and cardiovascular risk factors: Multiple potential mechanisms of actions. Nutrients 2017, 9, https://doi.org/10.3390/nu9111271.

50. Ros, E. Health benefits of nut consumption. Nutrients 2010, 2, 652 - 682, https://doi.org/10.3390/nu2070652.

51. Ros, E. Nuts and CVD. Br J Nutr 2015, 113, S111 - S120, https://doi.org/10.1017/S0007114514003924.

52. Alasalvar, C.; Salvadó, J.S.; Ros, E. Bioactives and health benefits of nuts and dried fruits. Food Chem 2020, 314, 126192, https://doi.org/10.1016/j.foodchem.2020.126192.

53. Müller, A.K.; Schmölz, L.; Wallert, M.; Schubert, M.; Schlörmann, W.; Glei, M.; Lorkowski, S. In vitro digested nut oils attenuate the lipopolysaccharide-induced inflammatory response in macrophages. Nutrients 2019, 11, https://doi.org/10.3390/nu11030503.

54. Poudyal, H.; Kumar, S.A.; Iyer, A.; Waanders, J.; Ward, L.C.; Brown, L. Responses to oleic, linoleic and $\alpha-$ linolenic acids in high-carbohydrate, high-fat diet-induced metabolic syndrome in rats. J Nutr Biochem 2013, 24, 1381 - 1392, https://doi.org/10.1016/j.jnutbio.2012.11.006.

55. Michalak, M.; Kieltyka-Dadasiewicz, A. Nut oils and their dietetic and cosmetic significance: A Review. $J$ Oleo Sci 2019, 68, 111 - 120, https://doi.org/10.5650/jos.ess18216. 
56. El Hawary, S.S.; Abubaker, M.; Abd El-Kader, E.M.; Mahrous, E.A. Phytochemical constituents and antityrosinase activity of Macadamia integrifolia leaves extract. Nat Prod Res 2020, 0, 1 - 6, https://doi.org/10.1080/14786419.2020.1849203.

57. Schlörmann, W.; Birringer, M.; Lochner, A.; Lorkowski, S.; Richter, I.; Rohrer, C.; Glei, M. In vitro fermentation of nuts results in the formation of butyrate and $\mathrm{c} 9, \mathrm{t} 11$ conjugated linoleic acid as chemopreventive metabolites. Eur J Nutr 2016, 55, 2063 - 2073, https://doi.org/10.1007/s00394-015-10200 .

58. Siddiqui, R.A.; Xu, Z.; Harvey, K.A.; Pavlina, T.M.; Becker, M.J.; Zaloga, G.P. Comparative study of the modulation of fructose/sucrose-induced hepatic steatosis by mixed lipid formulations varying in unsaturated fatty acid content. Nutr Metab 2015, 12, 1 - 14, https://doi.org/10.1186/s12986-015-0038-x. 